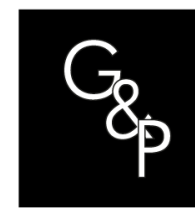

\title{
Work as management in an environment governed by standards: a study of situations in the steel industry
}

\author{
O trabalho como gestão num meio regido por padrões: um estudo \\ de situações no ramo siderúrgico
}

\author{
Adriana Carneiro $^{1}$ (D), Mônica de Fatima Bianco ${ }^{2}$ (D), Adelson Pereira do Nascimento ${ }^{3,4}$ (D) \\ ${ }^{1}$ Universidade Federal do Espírito Santo - UFES, Vitória, ES, Brasil. E-mail: linademellocarneiro@gmail.com \\ ${ }^{2}$ Universidade Federal do Espírito Santo - UFES, Programa de Pós-graduação em Administração - PPGAdm, \\ Vitória, ES, Brasil. E-mail: mofbianco@gmail.com \\ ${ }^{3}$ Instituto Federal do Espírito Santo - IFES, Serra, ES, Brasil. E-mail: adelsonpn@gmail.com \\ ${ }^{4}$ Universidade Federal do Espírito Santo - UFES, Vitória, ES, Brasil
}

How to cite: Carneiro, A., Bianco, M. F., \& Nascimento, A. P. (2021). Work as management in an environment governed by standards: a study of situations in the steel industry. Gestão \& Produção, 28(2), e5175. https://doi.org/10.1590/0104-530X5175-20

\begin{abstract}
This article aims to analyze the renormalization processes in work situations of technicians working in a testing laboratory of a steel company in Southeastern Brazil, explaining the contributions of the analytical perspective of Ergology when investigating how workers are organized to manage their activities in order to meet their production and quality goals, their personal as well as customer satisfaction, and protect themselves from work accidents. The qualitative research was carried out based on the analytical approach of Ergology, and the instruments used for data production were documentary investigation within the organization, direct observation of the activities, and semi-structured interviews with the participating workers. The data were treated using content analysis. It was found that these workers value standard operating procedures as tools to aid in the execution of their duties, but criticize them for being extensive, making consultation tiresome, and request more condensed, practical, and attractive procedures for handling. Research showed that certain unforeseen events in the process are only remedied by oneself and the other, demonstrating that the more complete a prescription is, collective experience fills any gaps, since the activity is more complex than anticipated by the standards. This study may contribute to a better understanding of situations common to the steel industry, as well as to academic progress, demarcating the importance of renormalizations not yet explored in this field of study - Ergology in the -Brazilian steel industry.
\end{abstract}

Keywords: Ergology; Management; Standardization; Work; Operating procedures.

Resumo: Este artigo procura analisar os processos de renormalização nas situações de trabalho dos Técnicos do laboratório de testes de uma empresa siderúrgica do sudeste do Brasil, explicitando as contribuições da perspectiva analítica da Ergologia ao investigar como os trabalhadores se organizam para gerir suas atividades visando atender as metas de produção e qualidade, a sua satisfação e a do cliente, além de se protegerem dos acidentes no trabalho. A pesquisa qualitativa foi realizada com base na abordagem analítica da Ergologia e os instrumentos para produção de dados foram consulta documental na organização, observação

Received Oct. 29, 2018 - Accepted Jan. 28, 2019

Financial support: None.

This is an Open Access article distributed under the terms of the Creative Commons Attribution License, which permits unrestricted use, distribution, and reproduction in any medium, provided the original work is properly cited. 
direta das atividades e entrevistas semiestruturadas com os trabalhadores participantes. Os dados foram tratados, utilizando-se a análise de conteúdo. Constatou-se que esses trabalhadores valorizam os procedimentos operacionais padronizados como ferramentas de auxílio na execução das atividades, porém os criticam por serem extensos, tornando a consulta cansativa, e solicitam procedimentos mais condensados, práticos e atrativos para o manuseio. A pesquisa evidenciou que certos imprevistos no processo somente são sanados pelo uso de si por si e pelo outro, demonstrando que por mais completa seja uma prescrição, a experiência do coletivo supre eventuais lacunas, pois a atividade se mostra mais complexa que os padrões permitam antecipá-la. Este estudo poderá contribuir para o esclarecimento das situações vivenciadas no ramo siderúrgico, e para o avanço acadêmico, demarcando a importância das renormalizações ainda não explorada nesse campo de estudo - Ergologia na siderurgia no Brasil.

Palavras-chave: Ergologia; Gestão; Padronização; Trabalho; Procedimentos operacionais.

\section{Introduction}

Standardization is directly related to industrialization, followed by the emergence of mass production and standardized work (Pompeu et al., 2015). With the use of specialized machines aimed at increasing productivity at a lower cost and in less time, new practices were adopted in production management, making it necessary to use standardization as a way to control the processes and product characteristics (Lodi \& Bastos, 2017). Since then, the development of formalized procedures has formed the basis of an entire industrial standardization process (Wiemes \& Balbinotti, 2012), which is one of the elements that currently ensures quality production is carried out, in addition to contributing to the ongoing improvement of processes that directly affect the cost, quality, and delivery time.

However, standardization has evolved with production models, such as lean production. When one thinks of the current standard, one no longer considers the type of standardization advocated in the context of classical management at a time when companies were concerned with mass production at the expense of customer satisfaction, whose efficiency was linked to reducing time and material waste. The responsibility for designing and changing production processes and determining the most appropriate way to perform a task was up to the supervisors and industrial engineers, leaving operators with no choice but to comply with them (Taylor, 1990).

Writing up standards is no longer restricted to supervisors and engineers. The participation of the operators who carry out the work has become a determining factor in this process, because it is the opinion of those who know the day-to-day working of the production process that defines the best standard (Pompeu et al., 2015). Due to ever-increasing competitiveness and quality requirements, industries have sought to control their processes, and standardization as one way to achieve that type of control (Campos, 1992). Also, standardization becomes increasingly present in organizations due to it being a requirement of ISO 9001. ISO SURVEY (ISO, 2009) presents the worldwide distribution of certification and Brazil was among the countries with the highest number of certified companies in 2013 (Teixeira et al., 2015). However, although history traces an evolution towards the participation of operators in developing standards, compliance with them continues being compulsory as a way to reduce costs, offer process variability, improve quality, increase productivity, preserve the environment, and protect employees from industrial accidents (Campos, 1992).

However, for a standardization system to be effective, it is not enough to simply draw up standards, but also keep them updated through periodic revisions (Campos, 1992). In a survey carried out by Nascimento et al. (2015), standardization continues 
to be a relevant factor for achieving management system maturity (be it quality management, work safety, or environmental management). In this study, carried out in 179 companies, it was shown that a correct understanding of customers' needs and making that information available to the employees in the form of procedures, instructions, and standards are important to management system maturation.

Conversely, Batista et al. (2016) emphasize that steelworkers try to reconcile the different demands they face (high levels of quality, productivity, safety, and sustainability) by developing various strategies as a way to safeguard their jobs, highlighting the multiplicity of mechanisms that the worker adopts for the job. Thus, rarefaction, segmentation, and fragmentation are part of the precarious environment of the prescriptions given to worker (Fernandes, 2018).

In the context of ergonomics, prescribed work is defined by managers, manuals, standards, instructions. and work orders that determine how goals are to be achieved. There is always a gap between prescribed work and actual work, because prescribed work cannot anticipate all the details involved in performing the work and the actual situation is always different from what was anticipated. The differences between what is demanded and what is actually happening must be managed (Duraffourg et al., 2010) in the activity, with work activity being understood as "[...] an always renewed rehearsal of a single person, who again acts in a configuration of the present, of the norms, at the same time prior to acting and anonymous [...]" (Schwartz \& Durrive, 2015, p. 383). They reinforce the idea of Ruzza et al. (2018) when they affirm it is impossible to fully standardize the unstable world in which we evolve, since living in a standardized world, entirely thought out by others, would be unlivable by a human being who needs to try to renormalize when faced with "rule gaps".

Telles \& Alvarez (2004, p. 72) state, with reference to Schwartz (2000a), "[...] ergonomics is a propaedeutic of ergology." However, they understand that the notion of antecedent norms used in ergology is more comprehensive than the prescribed work defined in ergonomics, although, as they point out, there is no difference in nature between the two. From a conceptual viewpoint, Daniellou (2004) finds that the works of Schwartz (2000a) and Clôt (1999) provide important contributions to the extension of the concept of activity in Francophonic ergonomics. Therefore, it is proposed in this article to think of work as the base of activity starting with the notions ergology presents.

Ergology is based on the approach to work and. in a more general way of human activity, assuming a constantly renewed exchange between actors from different disciplines, professionals and people engaged in economic activities with different levels of responsibility and branches of activity, as a way of creating concepts, in addition to understanding work situations to transform them (Schwartz \& Durrive, 2007, 2007). Figueiredo \& Athayde $(2005,174)$ write "[...] work, therefore, involves the mobilization of the body and the intelligence towards an objective of production, in which human ingenuity is objectified in such a way that work and oneself are produced in the same movement. "

Thus, in reaffirming the ergonomic assumption that there is a distance between prescribed and real work, ergology expands this discussion by adding three more propositions: '1) this distance is always partly singular because it cannot be totally anticipated, it is always introduced in the history of the one who works; 2) the one who manages this distance obeys a rationality that crosses the intellectual and biological as well as the cultural, the body-self, and 3) there are always values at play in the activity (Schwartz, 2010b). 
Activity management happens and expresses the individuality, the singular history, both individual and collective, of those who participate in the real moment of the activity (Trinquet, 2010). In this regard, Schwartz \& Durrive (2007) understands that human work always creates new norms by grabbing hold of what has been prescribed, leaving its mark and its record in the work it performs. Trinquet (2010, p. 96) describes, activity as the "[...] debate of norms and transgressions, which often results in renormalizations." Using the lens of Ergology to understand how workers act to follow so many standards required in the steel industry, the following objective was defined: to analyze the renormalization processes in work situations of technicians working at a testing laboratory of a steelmaking company in the Southeast of Brazil, explaining the contributions of this analytical perspective to understanding situations.

This article was organized in such a way that the main concepts of theoretical Ergology are discussed in item 2, aspects of the research method are discussed in item 3 ,, meaning how the research was conducted, detailing aspects of the production and analysis of the data, the importance of standards for the company and the testing laboratory is discussed in item 4 , and, finally, reflections resulting from this study are presented in item 5.

\section{Ergology: an analytical method in development}

The first concept is that work is intimately connected with the human. The existence of work occurs through the existence of man, who, when making use of himself, manifests himself as an individual, makes choices, organizes and reorganizes, imposes his vision of the world, leading to transformations and the existence of work. In this way, the diversity of individuals in the use of themselves, therefore conceiving work, presupposes new forms of how work is organized, resonating in complex relations. In addition, the use of self occurs in the immersion in a "medium" with "norms", leading to interaction and confrontation with subjective, organizational issues, constructing a diverse range of meanings (Schwartz, 2000b; Casadore, 2016).

Even with some weakening of Taylorist organizations in the past few decades, work remains in evidence until the present day, making it essential to better understand the transformations that have taken place in the world of work, the struggles, collective ties, analysis of knowledge, values, and the inadequacies and contradictions present in this environment (Schwartz, 2000b). Thus, the ergological approach to work arises from the collaboration of researchers Yves Schwartz (philosopher), Daniel Faïta (linguist), and Bernard Vuillon (sociologist), who are challenged by the mutations of worker and confronted with questions about the appropriate ways to prepare young workers to cope with such mutations, transcending economic and social life and, consequently, work activities (APST, 1991).

This approach has been under construction since the 1980s and 1990s in the French context and is based on various disciplines, such as philosophy, linguistics, sociology, psychology, ergonomics of activity, occupational medicine, law, and production engineering, so as to understand the complexity of work. Ergology appropriates the discussion on the philosophy of life of Georges Canguilhem (Canguilhem, 2001 ), enwrapped by the concept of health through the bias of human subjectivity and relying on two other important theoretical-epistemic and methodological references in order to collaborate in its formation, represented by the following researchers: Italian physician and psychologist Ivar Oddone and ergonomists Jacques Duraffourg and Alain Wisner (Schwartz, 2006; Schwartz et al., 2010). 
Thus, ergology is being consolidated as a multidisciplinary research approach. It is a process of dialogue between disciplines, without the intention of overcoming them: "[...] all are necessary, although none are sufficient [...]" (Trinquet, 2010, p. 94). The interest of Ergology lies in understanding the relationship of the worker to his activity. This understanding presupposes looking from the worker's perspective, recommending the need to enter the work places in order to listen to the workers and observe their activities. Consequently, it can be said that ergology is based on the episteme of ergonomics and expands upon it, since it intends to insert a different kind of knowledge into the dialogue (Schwartz \& Durrive, 2007) and can be seen as a philosophical thought, a way of understanding work as a space of construction and life that appropriates the knowledge of several scientific disciplines to analyze it without configuiring itself as science (Schwartz \& Durrive, 2007). In this sense, to understand the analytical approach adopted in this study, the following will be presented as its main concepts.

\subsection{Ergology: conceptual dialogues}

The ergological perspective aims to "[...] better know and, above all, better intervene on the work situations to transform them [...]" (Schwartz \& Durrive, 2007, p. 25) in favor of the psychic, intellectual and physical well-being of the worker, as affirmed by Schwartz \& Durrive (2007), a philosopher and main spokesperson for the ergological approach. In this paper, we present a discussion of the relationship between work and the health of those who perform it.

In this aspect, ergology was based on the distinction pointed out by ergonomics between prescribed work and actual work, but extended to the notion of antecedent norms and renormalizations. According to Telles \& Alvarez (2004), prescribed work does not only contemplate the norms, orders, and results to be obtained, but also the conditions that determine the work situation, such as the physical space, the raw materials used, and the socioeconomic conditions. According to Schwartz (2000b) and Schwartz \& Durrive (2015), the antecedent norms also precede the work activity, but differ from prescribed work and make human activity possible.

Ergology favors the concept of "antecedent norms", which is more comprehensive than its predecessor, considering the incorporation of various aspects of work situations, such as worker's intelligence, personal and collective experiences, knowhow, the constructions perceived as cultural and scientific assets, and the transcendent values of monetary issues, set by debates and conflicts and composing the hybridity of this concept (Telles \& Alvarez, 2004). As such, antecedent norms refer to the way in which collective experiences generate norms placed in a space-time, taking into account the singularity of each worker that composes the group, since they are permeated with individual and collective values (Schwartz, 2010a).

In this sense, managing the distance between the prescribed and the real conditions of work is what makes it possible to understand work as an activity. Work cannot be considered as a modest application of norms and procedures. It is the initial stage to understand the activity as a debate on standards (Nouroudine, 2011). Therefore, the debate on standards is the meeting point of all the forces that the worker performs to adapt to the work in the confrontation with the work standards, whereas renormalization is a product of the debate between the prescriptions that precede the work and the real work, that is, the work that is produced by the worker considering the individuality and singularity of each worker while executing the activity (Canguilhem, 2011). To exist as 
an individual, the human being will always try to reinterpret the standards proposed to him (Schwartz \& Durrive, 2015).

The management of the activity expresses the individuality, the singular history, both individual and collective, of those who participate in the real moment of the activity (Schwartz \& Durrive, 2007). With this in mind, it is understood that the worker always creates new standards, one way or another, by getting hold of what was prescribed and leaving his mark, his record in the work he performs (Trinquet, 2010). Schwartz \& Durrive $(2007,2007)$ conceptualize that the work addressed in the ergological perspective from a human activity viewpoint seeks to qualify the particular dynamics that workers live in work situations. In this way, by appropriating the work imposed on him from outside, embodied in the prescriptions, the worker does not disregard his history, his values, his unique way of being, permanently reinventing the prescribed standards (Schwartz \& Durrive, 2015). According to Schwartz (1994), to work is to manage a set of factors present at a given moment and space, for the benefit of a goal to be built. He further states that "to work is to manage (travailler, c'est gérer)" and administer oneself as an active subject by making use of oneself as a physical body and as body-self (corps-soi).

All work is constantly the use of self or the dramatic use of oneself: self-use, selfuse by others Schwartz (2003). In terms of ergology, workers must overcome the existing gaps in accordance with their perceptions and, thus, work cannot be executed in a standardized, absolute way and is always subject to variabilities, as we can aver in the following statement: "[...] norms do not anticipate everything, so to work is to take risks, to make use of oneself [...]" (Schwartz, 2010a, p. 191), reinforcing the idea that workers assume the risks and consequences of their decisions in making their choices, giving rise to the idea of drama and, consequently, the dramatic uses of oneself and others (Silva, 2016).

"Values" is a very relevant concept in ergology. It refers to the approximate weight attributed to things; a hierarchy, a categorization proper to each one on the subject of what is esteemed, preferred, or. on the contrary, is rejected, negligence. In a certain way, it is the attempt of each person to have mastery over the environment in which he finds himself. The individual does not develop his values alone or completely, but constantly reworks the ones that the environment proposes (Durrive \& Schwartz, 2008; Schwartz \& Durrive, 2015). Values permeate the micro-activity as well as across society as a whole and explain why a person does things one way and not another (Duraffourg et al., 2010). According to Holz \& Bianco (2014, p. 496), "[...] the entity that arbitrates and decides is not entirely biological, not entirely conscious or cultural, and that is why the idea of body-self is posed by the authors." Schwartz (2010b) complements by stating that once people make choices, whether conscious or unconscious, there are always values at play in the activity and concludes that it is because of criteria, and consequently because of values, that these choices are made, leading to "renormalizations".

This movement, which occurs when the subject makes choices between his norms and the impositions of the environment, his different or contradictory values, is called by ergology the dramatic uses of oneself, meaning it, consists of the dilemmas that the subject experiences when he has to make choices, and is often called upon to refer to himself. In this way, he draws out what is in his body-self, which understands what goes on both in his physical and mental body, and directly interferes with the way he will develop his task through his contextualised action (Pontes \& Santos, 2016). Therefore, "dramatic" refers to the fact that, at work, there is always a destiny that will be 
determined by the choices being constantly made. With choices, there are risks: "... to fail, to create new difficulties, to displease" and, at the same time, "[...] choosing this hypothesis is a way of choosing oneself - and is followed by having to assume the consequences of their choices [...]" (Schwartz et al., 2010, p. 191).

However, in situations, arbitrating between contradictory or different values and knowledge in search of solutions, Schwartz (1998) defines this movement as the dramatic use of self. This drama occurs in work situations, in a "meeting of singularities", of variabilities to be managed, and its boundaries are always indescribable and imprecise (Schwartz, 2010b). The subject's use of self at work is singular. In this sense, a "dramatique" is the place of a true micro-story in which each subject is forced to choose or orient their activity in this or another way. (Schwartz, 1998, p. 104).

According to Schwartz (2000b) and Trinquet (2010), acquired knowledge, academics, scientific knowledge, professional and disciplinary skills are external knowledge, prior to the work situation in question. This "[...] is the true knowledge, the knowledge that is in disarray with the activity, but which is the essence of prescribed work [...]" (Trinquet, 2010, p. 104). This prescribed work is confronted, in activity, with the invested knowledge that reflects daily actions, the practice, and is composed of the forces of convocation and reconvocation, generated by the knowledge produced through the experiences in diverse situations experienced by the workers. According to Brito (2004), the dialogue between acquired knowledge and invested knowledge deals with the ethics that builds the relationship between what is grounded in a philosophical vision of humanity and the individuals. This dialogue is established in the place where decisions are made, where the ways and means to solve a given problem are defined, the space of negotiation. Thus, the ergologic approach makes it so this knowledges complements and dialogues, which is essential to understanding the complex world of work and its relationship to workers' health.

The articulation between the knowledge constitutes a theoretical scheme for ergology to study and develop appropriate solutions that are capable of producing actions that meet the needs and demands coming from the world of work (Nouroudine, 2011; Schwartz, 2000b; Trinquet, 2010). In this sense, the workers' unique knowledge, values, and histories in confrontation with work guidelines, such as standardization and safety, propel the movement of the drama itself. The methodological aspects involved inthis research are presented in the following item.

\section{Methodological aspects of the research}

The approach to this research is qualitative. According to Minayo (2008), this perspective responds to very particular questions because it works with the universe of meanings, attitudes, aspirations, motives, beliefs, and values and concludes that this set of human phenomena is understood as part of social reality, because the human being is distinguished not only by acting, but also by thinking about what he does and interpreting his actions within and from the reality lived and shared with his peers.

Gaskell (2000) points out that qualitative research aims to investigate the different opinions and various representations on a theme in question, seeking to discover different points of view in this theme and, specifically, what justifies and substantiates them. The following is a discussion of the research details in regard to the site, subjects, production, and data processing. 
The company in question is a steel mill located in southeastern Brazil and produces hot plates and coils for different industrial segments. As a matter of confidentiality, the company will not be identified, so its name will be replaced by Açobrasil in the text and in the bibliographic references. The company carries out all stages of the production process: production of coke, sinter and pig iron, manufacture of liquid steel, slurry casting and rolling. It directly employs approximately 5,400 people distributed in three shifts from Monday to Sunday (AçoBrasil, 2018).

The choice of testing laboratory was in agreement with the organization after the demand for the research was carried out. The laboratory is responsible for performing tests that guarantee the mechanical properties of the coils and consists of two physical spaces -a reception and specimen preparation room (CP) and a testing room where the equipment is installed to conduct tensile strength, folding, charpy, and hardness tests. A documentary consultation was carried out for all the tests to understand the guiding procedures for the tasks executed by the laboratory's technicians.

The research subjects are technicians of the Testing Laboratory that analyzes and releases the steel company's final product. They work in two shifts a day, two technicians per shift taking turns in four letters, plus a worker to cover vacations, for a total of nine technicians. Of these nine workers, six agreed to participate in the interviews using a script. Observations were made of all shifts, focusing on all activities. All of the participants are male and have completed a technical course in mechanics with experience rangingfrom three months to thirteen years. In order to protect the their identifies, TEC (technical) codes followed by a number from 01 to 06 were used for identification purposes in the reports and the age and amount of experience of each one were not diclosed.

Relying on a data survey is the starting point of any scientific research. In this way, the researcher needs to define which technique is the most appropriate for collecting relevant information that provides the necessary support for analysis and conclusions in accordance with the research problem (Flick, 2008).

One of the means of producing data in this research was direct observation. This type of observation aims to complement the data production performed through semistructured interviews, making it possible to highlight the situational character of the action, giving legitimacy to the research with an ergological approach, which would not be possible by using only one data production technique (Bianco \& Holz, 2015). Direct observation lets the researcher observe the facts in a certain environment, aiming to thoroughly describe the subjects and the elements of a social situation, such as objects, instruments, events, and acts. Moreover, it produces data consolidated as facts, contributing to understanding the subjects'activities and experiences (Poupart et al., 2008).

The use of direct observation in this research allowed us to understand the subjects at work and their ways of acting in the presence of standards. After the documentary survey had been conducted, and due to the importance of knowing the work situations and being able to observe and interact with research subjects, we chose to use direct observation with a field diary as the main record-keeping tool. An observation script was applied in line with the ergological approach and the established objective. After two months of observation, made once a week for eight hours, the semi-structured interviews were conducted. The interview, taken in the strict sense of data production on a scientific theme and in the broad sense of verbal communication, is the strategy most frequently used in field work (Minayo, 2008). It corroborates Boni \& Quaresma (2005) by highlighting the fact that many people have more difficulty answering in 
writing than orally, and because they have more freedom and can give more spontaneous answers, respondents may ask unexpected questions, which can be extremely useful to the research.

All of the participating technicians were interviewed according to their availability and release by the area manager. The interviews were conducted at the workplace and lasted no more than two hours. Documentary consultation was necessary assess the existence of so many normative requirements in the workplace, since one of the ways ergology is used to analyze work situations is by understanding the distance between the prescribed and the real (Vieira \& Santos, 2012).

From the different techniques of data analysis and organization in qualitative research, Content Analysis (CA) was chosen to be used in this study out of all the other data collection and organization techniques available in qualitative research. Colbari (2014) mentions that the origins of CA are remote and inspired by day-to-day life, since classifying and categorizing are actions present in ordinary life.

Content analysis has been widely used in the field of management in Brazil, especially in qualitative research as one of the pertinent techniques of data analysis (Dellagnelo \& Silva, 2005). Our data analysis began with the transcription of the interviews and organization of the material from the field diary. Next, pre-analysis began (Bardin, 2011), in which all the data was explored through the organization process itself and then to a careful reading, punctuating the emerging categories of the analytical process, of which there were four: My story ... my work; Recognizing standards in work situations; The infidelity of the environment: it is necessary to renormalize to obtain results; and The transformations of work: a matter of security. Then, the process of detailing the categories began. After completing these two steps, interpretation was performed in the light of ergology, looking for the representations found in the workers' conversations (Câmara, 2013).

\section{Real work in the testing laboratory: encounter with the activities}

Any organization, regardless of size, needs a minimum number of procedures and norms to organize itself and remain in such a competitive market. When it comes to large organizations, prescriptions and standards are essential to keeping up with the demands of the national and international market, as well as those of their customers, community, suppliers, shareholders, and employees. Research showed us that Açobrasil does not fit outside this context as could be seen by looking at its cultural history. Standardization has been part of the company's culture since the beginning of its operations, reflected in its 6,000 current standards, which have become increasingly important due to the implementation of quality programs, the need to preserve the company's know-how as a result of employees' retiring, and control the processes due to the certifications it has earned.

With so many investments and so much pressure due to the certifications and the risks to which workers are exposed, compliance with the standards became the most important rule imposed by the company. It is even more stringently imposed in the testing laboratory, since the technical and operating procedures standards are developed, taking into account all the national and international technical standards required for each type of test to ensure they can be repeated under the same conditions anywhere in the world. In addition to the certifications mentioned above, the testing laboratory is accredited in ISO/IEC 17025 (ABNT, 2017). This standard establishes management and technical requirements for the implementation of a specific quality 
management system in testing laboratories that assures their customers an even greater reliability of test results.

During the field work, several prescriptions were observed that were present in the activities performed by the technicians that, according to the research objective, could not be ignored. The laboratory has 118 standards that describe the laboratory's activities. As the plant is certified to meet the Quality Management System (QMS), Environmental Management System (EMS) and the Health and Safety Management System (HSMS), the standards are prepared in an integrated way, meaning that one standard includes items that meet the requirements of the three aforementioned management systems. The standards are put together in a descriptive way, rich in detail, so as not to generate any doubt about them while executing the activities and ensure that no anomaly occurs in the course of performing the job. To explore how workers deal with so many controls, standards, and procedures, one has to first understand what the work means to them.

\subsection{My history ... my work}

According to Durrive \& Schwartz (2008), the meaning of work is a problematic notion, since each one attributes multiple meanings to the work he performs. For the authors, the meaning of work is the way each individual determines what has personal value as a means of work. In order to better understand work, it is important to understand its importance and meaning for each of these workers, because as Schwartz (2010c) says, in order to understand the work, it is necessary to know the history of of the person who does it. During the analyses, it was possible to show that, for the Laboratory workers, work is not just about economic and financial issues, which are also important, according to the workers' reports, but is also intertwined with feelings of happiness and well-being. For some technicians, the greatest importance of their work lies in the quality of the product and the reliability of the results they provide.

In order for the subject's fundamental curiosity to be solicited and activated by the encounter with the work situation, task needs to have meaning for him considering his unique history. The construction of the sense of work passes through recognition, the subject's gratification in relation to his own expectations for self-realization (Dejours et al., 2014). Work also applies as a means of professional achievement where the worker strives to satiate his desire for accomplishment, seeking his own satisfaction by virtue of the victories achieved and professional learning, as well as providing moments of pleasure and happiness that generate the satisfaction of feeling useful and more productive when working on something that one likes.

Here I perform professionally. Today I have the pleasure of working on what I like and studied and so I go in and leave feeling good and enthusiastic. For me it is a moment of fulfillment and gratification. We learn new things every day. (TEC02).

[...] but working here, doing what I learned, what I studied, what I like, I feel different. It makes me feel useful. It makes me feel that what I do has more than only financial value. People listen to what I say, my suggestions are taken into account. (TEC01).

Also, in the analyzes, it was also possible in the analyses to understand aspects of the workers' satisfaction with working for the company and particularly at the Testing Laboratory. The reasons are diverse and arise the satisfaction of working for a 
company this is internationally recognized for its direct and indirect salary, such as medical benefits, dental plan, and profit-sharing. Finally, pleasure in the work is also constituted by the gratification, the existence of valuation, the capacity that each one has to learn, and mainly by the pride in the work that is done (Lourenço et al., 2013). In this sense, autonomy in work is understood as the possibility to alter the prescription of its task and adapt it to the real one, allowing the worker to regulate the way the job is carried out. It is the degree of the worker's independence in relation to the prescriptions, objectives, and methods that constitute his work (Ferreira, 2010).

One thing I like very much here is the freedom we have to work. We have the freedom to manage our work. We can organize ourselves in the way that we think best and each one has his way of organizing. (TEC01).

\subsection{Recognizing the rules in work situations}

As stated above, the standardization culture is widespread in the testing laboratory, primarily based on the need to reduce accident risks, quality requirements, reliability of results, and customer satisfaction. It has been observed that, from the older workers to the new hires, they are familiar with the standards and show their naturalness when using them. Although Schwartz \& Durrive (2007) recognizes the difficulty of operationally defining the notion of competence, he mentions the mastery of protocols (technical and scientific knowledge) in a work situation as one of the ingredients of competence. (Schwartz \& Durrive, 2007; Bianco \& Holz, 2015).

Appreciation with respect to knowledge is also recognized by workers when they acquire knowledge as a form of investment in their career In some testimonials, it was possible to verify that work done is the permanent use of self. According to Schwartz (1994), when it is said that work is self-use, it means that it is a place of a problem, a problematic tension, a space of possibilities to negotiate: there is not only execution, but a continuous spectrum of modalities. It is the individual in his being that is summoned, with his resources and capacities infinitely greater than those which are explicit, which the daily task requires, even though this appeal may be globally sterilizing in relation to individual potentialities. In this way, in the calls and demands made to the worker, he makes use of himself for himself because work is the permanent stage of confrontations with values and standards. In the following section, the use of oneself and the other can be seen when the technician is mobilized when examining the debate of values experienced by the driver in the situation where he needs to decide between what should be done and what can be done, between productivity and security, but also having to meet the expectations of the other.

Sometimes it happens, for example, there's a dumpster with scrap in it out there and no one can touch it, there's a warning sign out there because of the risk of being cut. The driver who comes to take the dumpster ends up messing around with the dumpster before putting it in the truck ... then I go out there and I tell him not to do it, he could get cut, I come here to get a glove, what happens is the guy isn't doing it because he wants to do it ... it's because he's here in the area and he has no other way, he's being charged with releasing the equipment and he needs to take a piece of scrap that's out of place ...it's you putting yourself in the person's place as well ... it's an interesting conflict because he's not supposed to do it, but he has to do it. (TEC05). 


\subsection{The infidelity of the environment: it is necessary to renormalize to obtain results}

For Schwartz \& Durrive (2007), human activity is always a place of debate of antecedent norms and renormalizations that, influenced by the worker's values and choices, translates a re-reading of the prescribed one. The encounter of the antecedent norms with the singular activity against the impositions of the environment provokes a debate of norms resulting from the worker's confrontation with the antecedent norms and, as an outcome of this confrontation, the worker renormalizes and creates his own norm and makes his its mark. The author states that the work performed does not only correspond to the work that is expected and fixed by rules (Schwartz \& Durrive, 2007; Figueiredo \& Athayde, 2005). In the following situation, TEC01, confronted with the antecedent norms and the prescriptions imposed by the environment and even running the risk of displeasing his supervisor, made his own renormalizing choice, creating his own standard and transforming the work, since standards do not anticipate everything.

[...] I called maintenance, but they didn't show up, so there I was with a lot of material to release and I improvised by cutting the material in the metalographic cutter. Result: the cut was perfect and I was able to release the material and didn't have to wait for the maintenance to show up. The next day, I reported what happened to my supervisor and we ended up reviewing the standard. (TEC01)..

Therefore, to work is to risk, to make "self-use." (Schwartz, 2000b, p. 193) in order to renormalize the work situation presented to him and react to the unfaithful environment by assuming the consequences for his choices. There are always values at play, permeating the activities and explaining why we do things one way or another (Durrive \& Jacques, 2010; Schwartz \& Durrive , 2015). In order to understand how values guide choices, affect behavior and attitudes, and interfere with the way the worker gives meaning to work and appropriates the work that is imposed, there is an account by TEC03 that shows how the worker uses the values that permeate the activity and the use of oneself and the other to manage their activities according to the value he gives to his co-workers and the desire to feel useful to them and the company while carrying out their work in unforeseen situations (Bianco \& Holz, 2015). Besides being clear in this situation, there is a gap between the prescribed work and the actual work, which needs to be filled.

[...] We don't always receive the samples that were sent to the laboratory, those that are in the system for us to receive... so we have to run around to find out what happened, because they didn't arrive, etc ... or else we leave this pending for someone in the next shift to solve. So we spend a lot of time trying to solve this issue because if I don't do it, it will have to be done by my buddy in the next shift buddy. So why not take the burden off of him? (TEC03).

\subsection{Transformations of work: a safety issue}

The culture of prevention with respect to safety is one of the outstanding items in the steel company. "In this company, safety is a value. Anyone can refuse to perform an activity if risks to their physical integrity have been identified, and this is very important" (Field Notes). Safety, like standardization, is an ever-present value in the organization and recognized by the workers by the way the company disseminates and 
passes this on to the workers. To work is to manage a set of factors present at a given moment and space, for the sake of a goal to be built (Schwartz, 1994) and, in order to understand how workers construct and generate changes in their work, it was necessary to understand what safety represents both for the company and the workers. That way, one can understand how renormalizations transform work. As mentioned by the workers and recorded in the field diary, whatever theme is being disseminated to employees through the internal media, the standardization and safety themes will always be present one way or another. For instance, the testing laboratory includes both simple and sophisticated equipment, but all of them expose the workers to a different type of risk. In order to avoid these risks and provide greater safety for the worker, the company identifies the risks and control actions in the operationg procedures for each piece of equipment. Yet, even with so many controls, things do not always go according to plan. After all, the environment is unfaithful since the task is not always executed in the same way (Trinquet, 2010). As reported by the interviewees, imbued with safety values, workers are always using themselves to provide an increasingly safe environment for themselves and their co-workers, since it is they who organize, execute, and confront the situation at all times. Consequently, they are always negotiating, inventing, and reinventing ways to keep themselves safer by managing their activities and transforming the work situation. At this point, it is said that the worker makes use of his own resources and makes choices to manage the infidelities of the environment, as can be seen in the following report.

When we were going to put the $\mathrm{CP}$ in the traction machine, our hands were exposed to the equipment because you had to hold the CP with your hands and take it to the top two clamps and close them so it wouldn't let go during the test. So we racked our brains and came up with a safety device that made it so we wouldn't have to put our hands on anything to position the CP on the machine. And this simple tool has eliminated a risk from the standard and we now can do it safely. (TEC02).

The worker used his knowledge and put together a device that would prevent his co-workers from suffering the consequences due to the infidelity of the environment (Schwartz \& Durrive, 2007).

\section{Final considerations}

As we have seen, the steel industry is permeated with standards that bestow qualitative and quantitative benefits upon the sector. It is no different for this internationally recognized company, since from the beginning of its operations, a series of values formed over the years that became the company's culture with the participation of its employees who helped write its history. Customer requirements in a highly competitive market obliged it to acquire quality programs and certifications that led to more standards being established to maintain control of its processes.

When confronted with unforeseen events, the worker organizes the work imposed on him and makes choices and decisions in the face of the infidelity of the environment, based on the way he sees the world. This is because their stories and experiences constitute their body-self, reflecting and impacting on their decisions by putting the use of self for oneself and others into practice to meet the production goals and preserve health and safety for all. 
Ergology came along and strengthened the idea that it is necessary to consider not only the standards imposed, but also the worker taking into account the singularities involved in understanding the work. This study reinforced that human work can never be equated with prescribed work or the previous standards, as evidenced by the guiding concepts of analysis, that the participating workers create new standards by getting hold of what has been prescribed, leaving their mark, their record, and their contributions on the work they carry out, renormalizing it in accordance with Schwartz \& Durrive (2007) and Schwartz \& Durrive (2007).

Renormalization occurs while work is being executed, after constant debates on the standards, and they are influenced by the worker's values and choices, since they translate a re-reading of the prescribed activity. They do not go unnoticed by the company, either, in cases of improvement, as they give the employee a "voice" by having them implemented, such as issues involving safety and increased productivity. This reinforces job satisfaction and engagement, as these aspects are seen as recognition and autonomy from the workers' point of view. It may be said that work comprises the history of the subject as a matrix, producing energy and propelling innovations: "[...] insofar as the normalizing purpose is sometimes imposed upon being - the 'infidel' milieu, as 'reunion' claims that if one chooses one way or another to treat it [...] "(Schwartz, 1994, p. 4).

Many standards are present in the work environment, in compliance with the normative requirements imposed by certified management systems (QMS, EMS, and HSMS) and national and international technical standards needed to carry out the tests and that, as a result of so many demands, have made them extensive and tiring, in need of being improved in the way they were presented, making it easier to access and understand the information when using them. However, this factor did not seem so troublesome, since the technicians only used the standards as training before carrying out a task and as a form of consultation when they felt the need to do so. According to the technicians' report, the company is working on a new standardization system to make them more attractive to workers. However, this need is being cut due to workers placing a high value on invested knowledge as a form of security and confidence while also recognizingthe experience of their co-workers and relying on them in case of doubts. The worker is able to manage the job against the unexpected, transforming the work and self. In the observation of the actual work, it was noticed, as the theory already predicted (Daniellou, 2004; Durrive \& Schwartz, 2007, 2008), that company standards do not foresee everything and workers themselves manage the gap in the situation using their experience, know-how, and invested knowledge to account for their activity in the face of unforeseen events and the organization's expected results., They make their own choices after arbitrating between different and contradictory values at the risk of failing or displeasing a supervisor and accepting the consequences of their choices. The difficulty of having some standards that do not fully encompass the complexity of the activities was also mentioned by the respondents. Such a finding, that there are always gaps to be filled, however standardized the activities may be, are consistent with theory, since the worker recognizes this irreducible distance between reality and the prescriptions contained in the procedures (Dejours et al., 2014; Figueiredo \& Athayde, 2005).

The reports show that the workers strive to reduce the gaps in real work, which the previous standards do not cover. Thus, "self-use" and the imposed standards point to a better way of doing things, which demand careful attention by the workers, who are caught between "a rock and a hard place" and must act with responsibility and 
intelligence so as not to run the risk of breaching a standard, yet do the job and achieve the expected results.

This study contributes to the field of management in a theoretical and empirical way. From the theoretical point of view, it contributes to a better understanding of the steelmaking environment and the renormalization that takes place in the workers' routine, revealing spaces for creation where the standard wants to overlap. In an empirical way, this work reinforces the importance of taking into account the singularity of the activities, since they are permeated with individual and collective values, invested knowledge, and environmental variables as a reference when developing activities, giving relevance to the analysis of work from the perspective of ergology so as to meet the expectations of the work required in the contemporary organizational context.

\section{References}

AçoBrasil. (2018). Dados do setor siderúrgico. Retrieved in 2017, March 20, from http://www.acobrasil.org.br/site2015/indicadores.asp

Analyse Pluridisciplinaire Des Situations De Travail - APST. (1991). Revue du IRETEP. Número especial. Regards nouveaux sur le travail, Ivrysur-Seine, 9, jan-mars.

Associação Brasileira de Normas Técnicas - ABNT (2017). NBR ISO/IEC 17025: Requisitos gerais sobre a competência dos laboratórios de ensaio e calibração. Rio de Janeiro: ABNT.

Bardin, L. (2011). Análise de conteúdo. São Paulo: Edições.

Batista, M. L., Lima, M. E. A., \& Antipoff, R. B. F. (2016). A preservação da saúde em situações patogênicas de trabalho: um estudo de caso na siderurgia. Cadernos de Psicologia Social do Trabalho, 19(1), 45-59. http://dx.doi.org/10.11606/issn.1981-0490.v19i1p45-59.

Bianco, M. F., \& Holz, E. B. (2015). Trabalho e competência industriosa: uma cartografia ergológica no setor de rochas ornamentais no Brasil. Ergologia, 4, 47-72.

Boni, V., \& Quaresma, S. J. (2005). Aprendendo a entrevistar: como fazer entrevistas em Ciências Sociais. Em Tese, 2(1), 68-80.

Brito, J. (2004). Saúde do trabalhador: reflexões a partir da abordagem ergológica. In M. Figueiredo, M. Athayde, J. Brito, \& D. Alvarez (Orgs.). Labirintos do trabalho: interrogações e olhares sobre o trabalho vivo (pp. 91-114). Rio de Janeiro: DP\&A.

Câmara, R. H. (2013). Análise de conteúdo: da teoria à prática em pesquisas sociais aplicadas às organizações. Gerais. Revista Interinstitucional de Psicologia, 6(2), 179-191.

Campos, V. F. (1992). TQC: Controle da Qualidade Total (6a ed.). Belo Horizonte: Fundação Christiano Ottoni, 1992.

Canguilhem, G. (2001). Meio e normas do homem no trabalho. Pro-Posições, 12(2-3), 109-121.

Canguilhem, G. (2011). O normal e o patológico (7a ed.). Rio de Janeiro: Forense Universitária.

Casadore, M. M. (2016). Sobre os aspectos clínicos e a complexidade do trabalho: as clínicas do trabalho compreendidas pela perspectiva da Psicossociologia. Cadernos de Psicologia Social do Trabalho, 19(2), 177-185. http://dx.doi.org/10.11606/issn.1981-0490.v19i2p177185.

Clôt, Y. (1999). La fonction psychologique du travail. Paris: PUF.

Colbari, A. (2014). Cultura da inovação e racionalidade econômica no universo do pequeno empreendimento. Interações (Campo Grande), 15(2), 237-247. 
Daniellou, F. (2004). Apresentação à edição brasileira. In F. Daniellou (Coord.) A Ergonomia em busca de seus princípios: debates epistemológicos (pp. VII-X). São Paulo: Edgard Blücher.

Dejours, C., Abdoucheli, E., \& Jayet, C. (2014). Psicodinâmica do Trabalho: contribuições da Escola Dejouriana à análise da relação prazer, sofrimento e trabalho. São Paulo: Atlas.

Dellagnelo, E. H., \& Silva, R. C. (2005). Análise de conteúdo e sua aplicação em pesquisa na administração. In M. M. F. Vieira, \& D. M. Zovain (Orgs.), Pesquisa qualitativa em administração: teoria e prática (pp. 97-118). São Paulo: FGV.

Duraffourg, J., Duc, M., \& Durrive, L. (2010). O trabalho e o ponto de vista da atividade. In Y. Schwartz, \& L. Durrive (Orgs.), Trabalho e Ergologia: conversas sobre a atividade humana (2a ed., pp. 47-87). Niterói: EdUFF.

Durrive, L., \& Jacques, A. M. (2010). O formador ergológico ou "Ergoformador": uma introdução à ergoformação. In Y. Schwartz, \& L. Durrive (Orgs.). Trabalho e Ergologia: conversas sobre a atividade humana (2a ed., pp. 295-307). Niterói: EdUFF.

Durrive, L., \& Schwartz, Y. (2007). Trabalho \& Ergologia: conversas sobre a atividade humana. Niterói: EdUFF.

Durrive, L., \& Schwartz, Y. (2008). Revisões temáticas: glossário da Ergologia. Laboreal (Porto), 4(1), 23-28. http://dx.doi.org/10.4000/laboreal.11665.

Fernandes, J. L. (2018). Trabalho informal e desenvolvimentos: introdução. Ergologia, trabalho, desenvolvimentos. Porto: FPCEUP.

Ferreira, M. C. (2010). Chegar feliz e sair feliz do trabalho: aportes do reconhecimento no trabalho para uma ergonomia aplicada à qualidade de vida no trabalho. In A. M. Mendes (Org.), Trabalho e saúde: o sujeito entre a emancipação e a servidão. Curitiba: Juruá.

Figueiredo, M. G., \& Athayde, M. R. C. (2005). Organização do trabalho, subjetividade e confiabilidade na atividade de mergulho profundo. Revista Produção, 15(2), 172-183. http://dx.doi.org/10.1590/S0103-65132005000200004.

Flick, U. (2008). Introdução à pesquisa qualitativa (3a ed.). Porto Alegre: Artmed Editora.

Gaskell, G. (2000). Entrevistas individuais e grupais. In M. W Bauer, \& G. Gaskell (Orgs.), Pesquisa qualitativa com texto, imagem e som: um manual prático. Petrópolis: Vozes.

Holz, E. B., \& Bianco, M. F. (2014). Ergologia: uma abordagem possível para os estudos organizacionais sobre trabalho. Cadernos EBAPE.BR, 12(spe), 494-512. http://dx.doi.org/10.1590/1679-39519106.

International Standard Organization - ISO (2009). The ISO Survey 2009. Genebra: International Standard Organization.

Lodi, S. G., \& Bastos, F. C. C. (2017). A importância da padronização organizacional: um estudo de caso na área educacional. Revista Borges, 6(2), 15-25.

Lourenço, C. D. D. S., Ferreira, P. A., \& Brito, M. J. D. (2013). O significado do trabalho para uma executiva: a dicotomia prazer e sofrimento. Organizações em Contexto, 9(17), 247279.

Minayo, M. C. S. (2008). O desafio do conhecimento (11a ed.). São Paulo: Hucitec.

Nascimento, A., Oliveira, M., Zanquetto, H., Fo., \& Ladeira, M. (2015). Idade versus Maturidade: uma pesquisa empírica sobre Sistemas de Gestão da Qualidade. Sistemas \& Gestão, 10(1), 108-123. http://dx.doi.org/10.7177/sg.2015.v10.n1.a9.

Nouroudine, A. (2011). Como conhecer o trabalho quando o trabalho não é mais o trabalho? Trabalho, Educação e Saúde, 9(Supl. 1), 69-83. http://dx.doi.org/10.1590/S198177462011000400004.

Pompeu, A. M., Pinheiro, J. A. S., \& Rabaioli, V. (2015). Os modelos de produção e o trabalho padronizado: uma abordagem da produção artesanal à produção enxuta. Multitemas, 47, 89-108. 
Pontes, C. R. M., \& Santos, E. H. (2016). Debate de normas e valores vivenciado pelo sujeito na atividade do trabalho. Revista Agenda Social, 9(1), 8-18.

Poupart, J., Deslauriers, J. P., Groulx, L. H., Laperrière, A., Mayer, R., \& Pires, A. (2008). A pesquisa qualitativa: enfoques epistemológicos e metodológicos. Petrópolis: Rio de Janeiro.

Ruzza, R., Lacomblez, M., \& Santos, M. (2018). Ergologia, trabalho, desenvolvimentos. Belo Horizonte: Fabrefactum.

Schwartz, Y. (1994). Trabalho e Gestão: níveis, critérios, instâncias. In M. Figueiredo, M. Athayde, J. Brito, \& D. Alvarez (Orgs.), Labirintos do Trabalho: interrogações e olhares sobre o trabalho vivo. Rio de Janeiro: DP\&A.

Schwartz, Y. (1998). Os ingredientes da competência: um exercício necessário para uma questão insolúvel. Educação \& Sociedade, 19(65), 101-140. http://dx.doi.org/10.1590/S0101-73301998000400004.

Schwartz, Y. (2000a). Le paradigme ergologique ou un métier de Philosophe. Toulouse: Octarès.

Schwartz, Y. (2000b). A comunidade ampliada e o regime de produção de saberes. Trabalho \& Educação, 7(7), 38-46.

Schwartz, Y. (2003). Trabalho e uso de si. In Y. Schwartz, \& L. Durrive (Orgs.), Travail \& Ergologie: Entretiens sur l'activité humaine. Toulouse: Octarès Editions.

Schwartz, Y. (2006). Entrevista. Revista Trabalho, Educação e Saúde, 4(2), 457-466.

Schwartz, Y. (2010a). Reflexão em torno de um exemplo de trabalho operário. In Y. Schwartz, \& L. Durrive (Orgs.), Trabalho \& Ergologia: conversas sobre a atividade humana (2a ed., pp. 37-46). Niterói: EdUFF.

Schwartz, Y. (2010b). Uso de si e competência. In Y. Schwartz, \& L. Durrive (Orgs.). Trabalho \& Ergologia: conversas sobre a atividade humana (2a ed., pp. 205-221). Niterói: EdUFF.

Schwartz, Y. (2010c). A experiência é formadora? Educação e Realidade, 35(1), 35-48.

Schwartz, Y., \& Durrive, L. (2007). Trabalho \& Ergologia: conversas sobre a atividade humana. Niterói: EdUFF.

Schwartz, Y., \& Durrive, L. (Orgs.). (2015). Trabalho e Ergologia II: diálogos sobre a atividade humana. Belo Horizonte: Fabrefactum.

Schwartz, Y., Duc, M., \& Durrive, L. (2010). A linguagem em trabalho. In Y. Schwartz, \& L. Durrive (Orgs.), Trabalho \& Ergologia: conversas sobre a atividade humana (2a ed., pp. 131-148). Niterói: EdUFF.

Silva, L. A. (2016). Normalizações e usos de si no trabalho: estudo de caso em uma indústria metal-mecânica. Trabalho e Educação, 25(3), 223-224.

Taylor, F. W. (1990). Princípios de administração científica. São Paulo: Atlas.

Teixeira, C. S., Vigano, F. R., Corrêa, G. A., \& Bastos, R. C. (2015). O status atual das certificações no Brasil: um olhar sob A ISO 9001, ISO 14001 E OHSAS 18001. Revista Inova Ação, 4(1), 84-109.

Telles, A. L., \& Alvarez, D. (2004). Interfaces ergonomia-ergologia: uma discussão sobre trabalho prescrito e normas antecedentes. In M. Figueiredo (Org.), Labirintos do trabalho: interrogações e olhares sobre o trabalho vivo (pp. 63-90). Rio de Janeiro: DP\&A.

Trinquet, P. (2010). Trabalho e educação: o método ergológico. Revista Histedbr, 10(38e), 93113. https://doi.org/10.20396/rho.v10i38e.8639753.

Vieira, P. R., Jr., \& Santos, E. H. (2012). A gênese da perspectiva ergológica: cenário de construção e conceitos derivados. Trabalho e Educação, 21, 83-100.

Wiemes, L., \& Balbinotti, G. (2012). A padronização de processo produtivo em uma indústria automobilística: uma análise teórico prática. Conhecimento Interativo, 5(2), 84-97. 